\title{
FINANCING SUSTAINABLE DEVELOPMENT WITH ENHANCED DOMESTIC RESOURCE MOBILIZATION: TRANSITIONAL ROLE OF INTERNATIONAL COOPERATION
}

\author{
Koji Yamada*
}

The Sustainable Development Goals are very comprehensive, reflecting the increased diversification and complication involved with the development challenges the world is facing in the post-2015 period. Also taking place is a dramatic change in the global landscape of development finance, in which domestic public revenues have risen rapidly to become the largest source of finance. Official development assistance (ODA) for domestic resource mobilization (DRM) will remain essential to accelerate economic growth and lift people from extreme poverty, particularly in the low-income countries. The combination of technical assistance and increased financing for capacity-building can play a vital role in strengthening DRM and lead to more effective and efficient use of public expenditure. The present report first reviews the latest literature on the rationale for this path and the emphasis on public domestic resource mobilization. It then looks at the two-decade experience of the Japan International Cooperation Agency (JICA) with the Mongolian tax authority as an example of international cooperation that supports enhanced DRM. After reviewing the events chronologically from the mid-1990s to the 2010s, key takeaways from JICA are given with a focus on capacity development. Finally, the report discusses the transitional role of international cooperation in this regard. It points out that to effectively carry out capacity development, a long-term commitment and joint concerted efforts from the global community are needed. This, in turn, requires a change in mindset from being oriented towards results management at the individual project level to applying programme-based management, which entails combining different types

* Chief Representative, JICA Bhutan Office, Thimphu, Bhutan (e-mail: Yamada.Koji@jica.go.jp). 
of operations to meet the national development goals and strategy. In addition, it must go hand-in-hand with strong country ownership to come up with indigenous solutions. In the case involving JICA and the Mongolian tax authority, implementing quick-impact projects and showing the impacts at each stage has convinced the latter of the need for a long-term commitment to the results. The long-term commitment of traditional donors from the North could facilitate the participation of emerging donors in a concerted manner. It could scale up capacity development efforts by facilitating triangular cooperation to promote DRM in many countries.

JEL classification: $\mathrm{H} 21, \mathrm{~K} 34, \mathrm{Q} 01$.

Keywords: Sustainable Development Goals, capacity development, taxation, domestic resource mobilization, Global Partnership for Effective Development Cooperation (GPEDC), triangular cooperation.

\section{INTRODUCTION}

The Third International Conference on Financing for Development, held in Addis Ababa in July 2015, adopted the Addis Ababa Action Agenda (AAAA). In the Agenda, the Conference called for the global community to make a strong commitment to achieve all the Sustainable Development Goals, which were agreed upon later in the same year at the United Nations Summit on Sustainable Development in New York. ${ }^{1}$ Compared with their predecessor, the Millennium Development Goals, the Sustainable Development Goals are comprised of more goals and associated targets, which amplifies the increased diversification and complications involve with development challenges the world is facing in the post-2015 period.

Prior to the Third International Conference on Financing for Development, the Joint Ministerial Committee of the Boards of Governors of the World Bank and the International Monetary Fund (IMF) discussed measures to transfer real resources to developing countries based on a report jointly prepared by the Wold Bank, IMF and other regional development institutions. The report titled "From billions to trillions," reflects the shift in the global landscape of development finance. The following is written in the preface of the report:

See A/RES/69/313. 
To meet the investment needed to achieve the Sustainable Development Goals, the global community needs to move the discussion from "billions" in overseas development assistance (ODA) to "trillions" in investments the public and private sectors, national and global, and in both capital and capacity. (AfDB and others, 2015, p. 1)

In the report, it is then written that despite the dire need for funds to achieve the proposed Sustainable Development Goals globally, ODA resources available at the beginning of the post-2015 period were estimated to be about $\$ 135$ billion per annum. While the global community continues in its efforts to increase the volume of ODA flow and reach the 0.7 per cent target of gross national income ( $\mathrm{GNI})$, it states that ODA alone will be insufficient and that other international financial flows, such as philanthropy, remittances, South-South flows and foreign direct investments (FDIs) totalling almost $\$ 1$ trillion per annum will be needed to close the funding gap.

The report also highlights that development financing at the national level in the form of domestic public resources is the most substantial source of funds, even though the largest potential lies in financing from private sector. It emphasizes that each country and the global community must support this trajectory from billions to trillions.

The present report reviews literature that supports this investment path, and emphasizes domestic resource mobilization (DRM), focusing on the public resources. Then the two-decade-long experience of the Japan International Cooperation Agency (JICA) with the Mongolian tax authority is reviewed as an example of international cooperation that supports enhanced DRM. Reviewing events chronologically from the mid-1990s to the 2010s, the report then contains a discussion on the key takeaways from their experience through the lens of capacity development. It concludes with a discussion on the transitional role of international cooperation in this regard.

\section{RATIONALE FOR DOMESTIC RESOURCES MOBILIZATION}

A dramatic change in the global landscape of development finance has occurred since the turn of the century (figure 1). Domestic public revenues have risen rapidly to about $\$ 5.5$ trillion to become the largest source of finance, while domestic private resources have quadrupled to reach about $\$ 4$ trillion. Meanwhile, international public finance, net ODA and other official flows, have increased only moderately, resulting in a small absolute amount and declining relative importance as a source of development finance. 
Figure 1. Trends in finance to developing countries, 2002-2011 (\$ billion, 2011 prices)

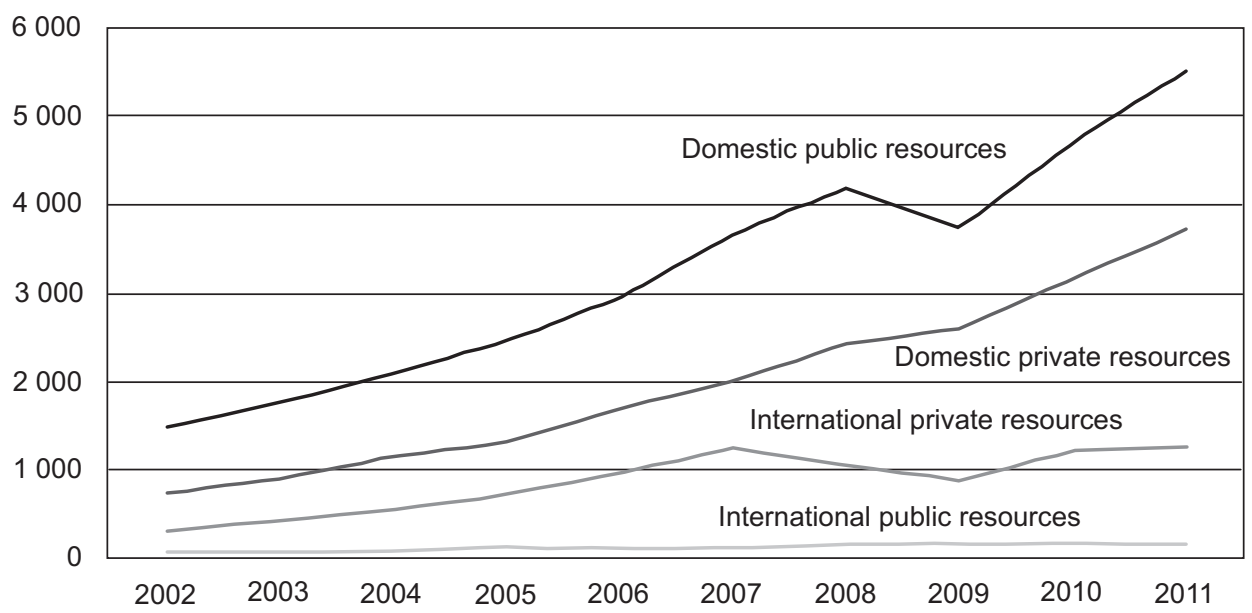

Source: ODI and others (2015a).

The composition of finance also varies in accordance with the development stages of the countries measured by the level of income per capita. It shows that as countries advance to higher income levels, they tend to experience declining ratios of ODA relative to gross domestic product (GDP) and increasing tax revenues relative to GDP. Private domestic finance has tended to rise more rapidly, but it still remains much lower as a percentage of GDP in the low-income countries. Also of note, remittances are an important source of development finance for the low-income and lower-middle-income countries.

These empirical facts imply that each country must consider the transition of the source of development finance in accordance with its level of national income per capita. The European Centre for Development Policy Management (ECDPM) illustrates this typical evolution in the source of finance based on their country case studies on Bangladesh, Ecuador, Indonesia, Mauritius, Moldova and the United Republic of Tanzania (ODI and others, 2015a). In general, their evolution has followed an upward trajectory from international public finance to domestic public finance, and then to domestic and international private finance (figure 2). ECDPM further argues that with regard to low-income and lower-middle-income countries, there is space to increase tax revenues, which is the most sustainable source of finance for critical infrastructure and climate-resilient and social development. Public-private partnerships (PPPs) are a promising option for these countries to meet infrastructure 
needs that exceed government budgets. To differing degrees, ODA can continue to play a catalytic role in all the case countries, since it is largely directed towards small and strategic projects pertaining to climate resilience, trade finance, health, education and infrastructure.

\section{Figure 2. Typical evolution in sources of development finance}

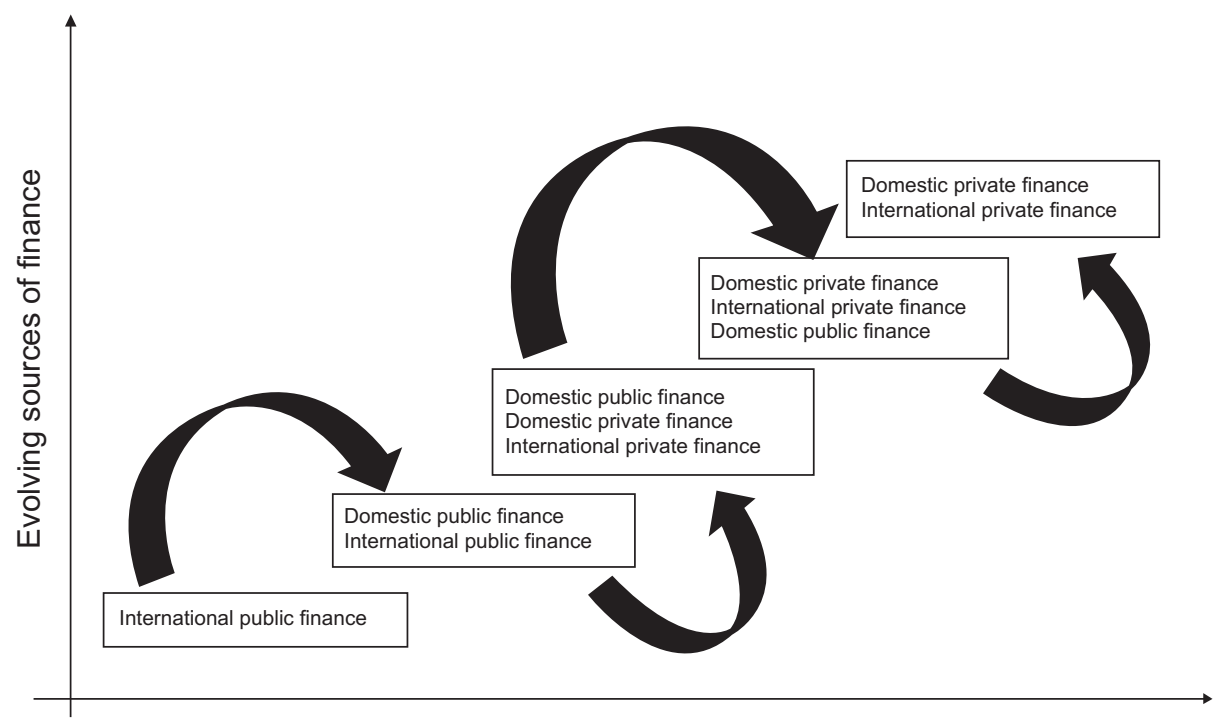

Level of income

Source: ODI and others (2015b). Revised by the author.

Looking ahead at the post-2015 era, in an analysis of the available sector studies, estimates indicate that incremental spending needs for achieving the Sustainable Development Goals annual investment in the lower-income countries and lower-middle-income countries to be at least \$1.3 trillion per year (table 1). A number of economies have graduated from the lower-income country status to the middleincome country status over the past 15 years. Due to their sustained economic growth, they have greater space for DRM, both public and private, to do the following: correct in-country inequality; promote capacity development for national statistics and data revolution; finance infrastructure development; and initiate South-South cooperation.

Further emergence of the global South-South development efforts to mobilize international resources now appears more likely. ODA from developed countries and domestic public resources will still be needed to accelerate economic growth and lift 


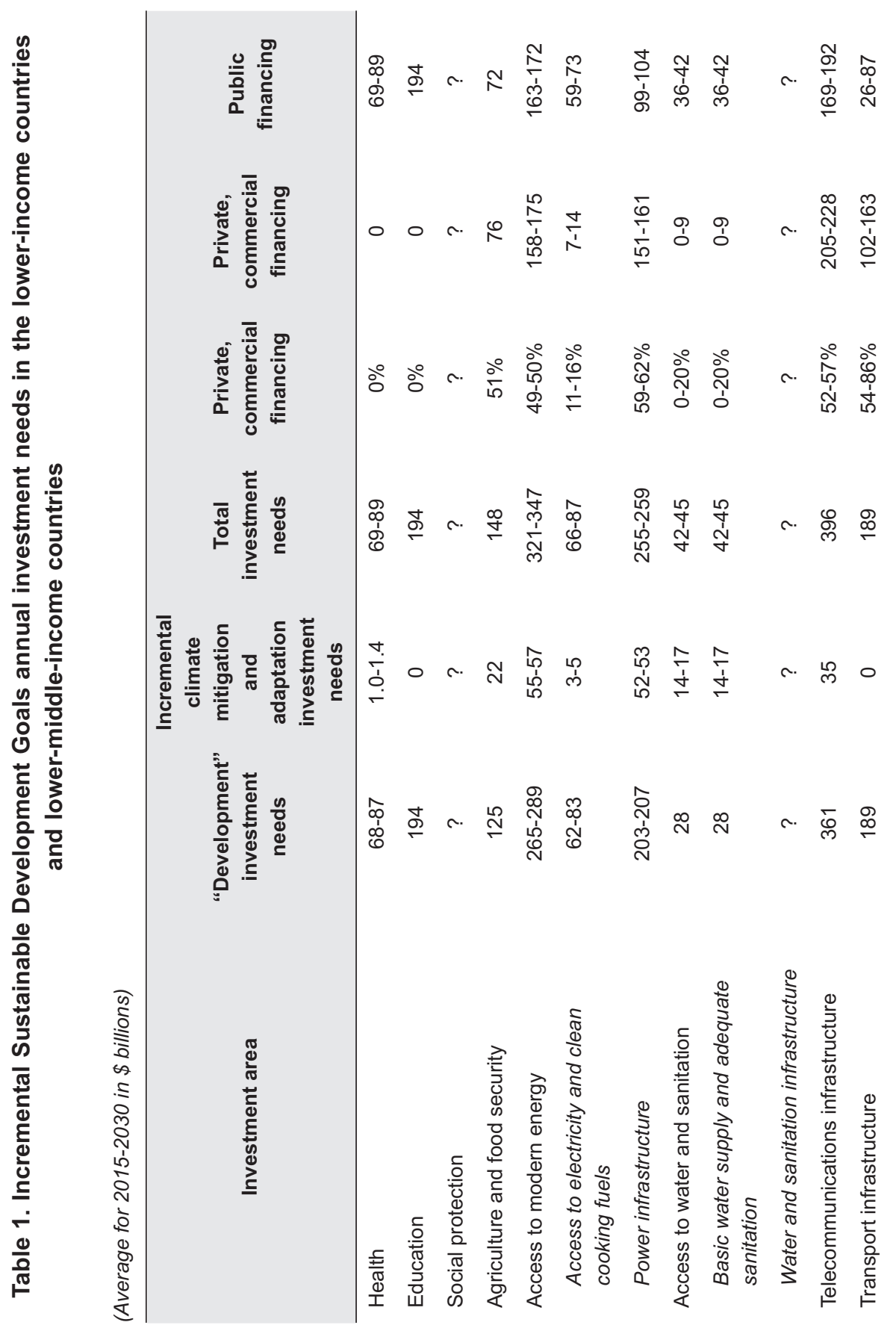




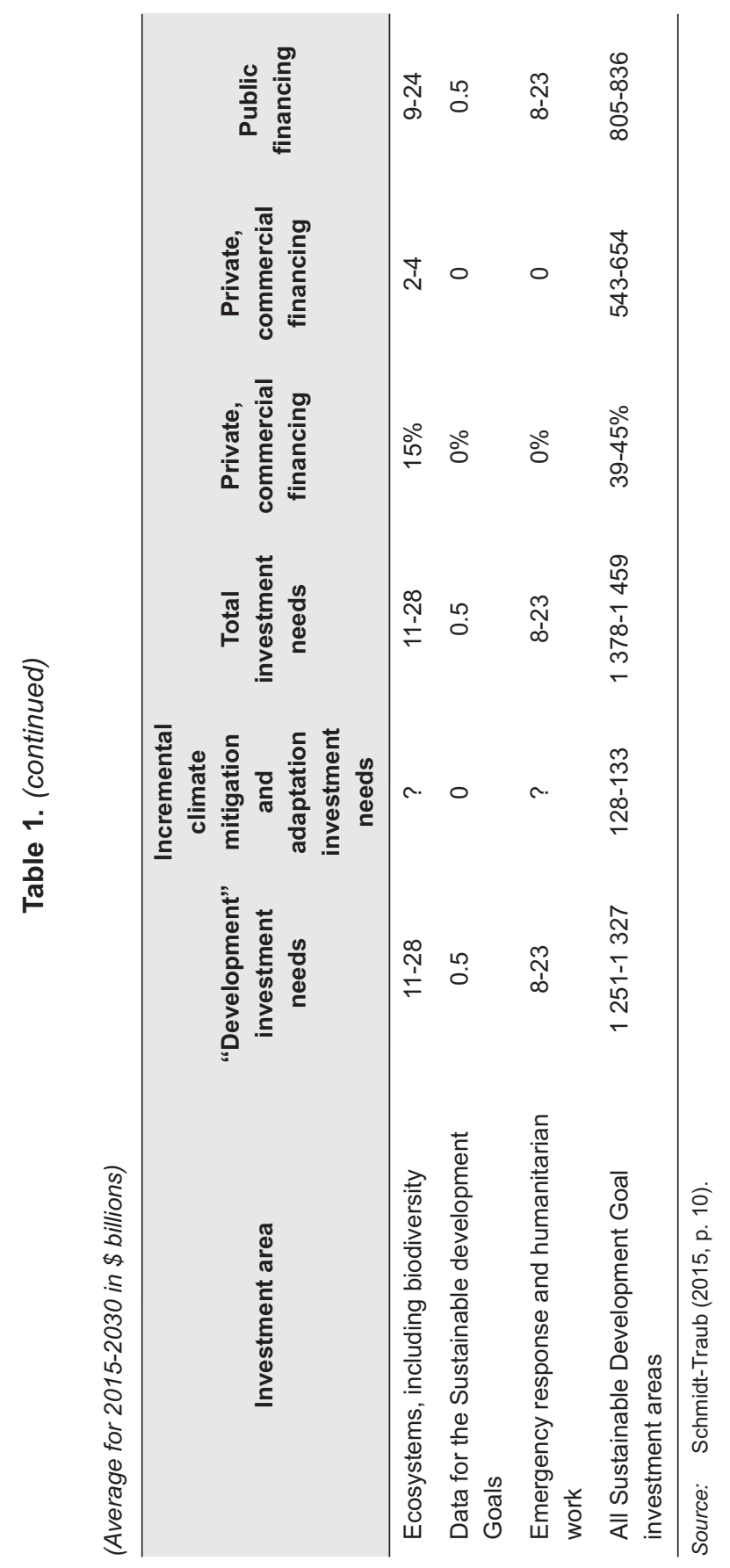


people from extreme poverty, particularly in the lower-income countries. As countries move to the upper bracket of income per capita, however, they will be challenged with how to transfer key responsibilities for financing development from international public finance to domestic public finance.

It should be noted that while this report highlights the source side of development finance, it also includes discussions on using financial resources that have already been mobilized. ODI and others (2015a) also proposes an analytical framework by raising the following two key questions:

(a) How can financial resources be effectively mobilized?

(b) How should financial resources be channelled and how can they be combined with selected policies to enable a transformative 2030 agenda?

Then, it argues that appropriate national and international policies matter, for both sourcing and using development finance.

Table 2 provides a policy framework consisting of policy options at both national and international levels. Implementing domestic policies that are aimed at helping to increase the mobilization of funds and more efficiently use financial resources eventually leads to further DRM and a conducive global environment that attracts international private financial flows. As for the use of financial flows described above, there are two additional issues that need to be considered: (a) prioritization of policy targets based on cost-effectiveness; and (b) enhancement of the effectiveness of development finance. Nevertheless, the main focus of this report is on the source side at the national level.

\section{Table 2. Key policy areas for financial flows}

\begin{tabular}{lllll}
\hline & \multicolumn{2}{c}{ Source } & & \multicolumn{1}{c}{ Use } \\
\hline National & $\checkmark$ & Regulatory framework & $\checkmark$ & National capacity development \\
& $\checkmark$ & Financial sector instruments & $\checkmark$ & Standards, transparency \\
& $\checkmark$ & Public sector capacity & $\checkmark$ & Regulatory framework \\
& & development, such as project & $\checkmark$ & Policy coherence, such as trade \\
& & preparation and tax collection & & policy \\
\hline International & $\checkmark$ & Development finance & $\checkmark$ & Global rules/standards \\
& & institutions/special funds/new & $\checkmark$ & Donor coordination and \\
& & development banks & & development finance institutions \\
& $\checkmark$ & International policy environment \\
& & & \\
& & & \\
& (trade, tax, climate finance) & &
\end{tabular}

Source: ODI and others (2015b). Revised by the author. 


\section{CASE STUDY ON TECHNICAL COOPERATION FOR DOMESTIC RESOURCE MOBILIZATION - TAX ADMINISTRATION IN MONGOLIA}

Multilateral development banks stress that countries should take the lead in mobilizing and spending their domestic resources, but they admit that measures to improve DRM and public expenditures can vary across countries and that their implementation may be beset by political economic constraints. To address these challenges, they point out that the combination of technical assistance and increased financing for capacity-building can play a vital role in strengthening DRM and lead to more effective and efficient use of public expenditure (AfDB and others, 2015).

Domestic resource mobilization is also referred in the Sustainable Development Goals. Specifically, Goal 17.1 is "Strengthen domestic resource mobilization, including through international support to developing countries, to improve domestic capacity for tax and other revenue collection."2

While multilateral development banks and IMF insist that they are in a position to support countries' efforts to strengthen DRM, other providers of development cooperation may also play a vital role in supporting them. For example, the work of JICA of 20 years in providing technical support to develop capacity in the tax administration in Mongolia must also be considered. Based on the documents available at the Industrial Development and Public Policy Department, this section reviews the experience of JICA in Mongolia.

When Mongolia went from being a socialist regime to democratization in 1990 , the country's tax administration had been facing all kinds of problems, including, among them, putting in place an inadequate legal system, a malfunctioning organization, limited human resources and the lack of an environment for paying taxes. The absence of a modern tax collection system under the socialist regime resulted in a chronic revenue shortfall and fiscal deficit. As its transition to a marketoriented economy progressed, tax revenue in Mongolia increased more than 30 times from the initial level. Revenue growth since the mid-2000s has been substantial (figure 3).

Sales tax and value-added tax (VAT), corporate income tax and personal income tax comprise the major portion of tax revenue sources in Mongolia, accounting for 42.7 per cent of the revenue in 2013. Other revenue sources are social security contributions, excise taxes, customs duties and export taxes, and non-tax revenues. The revenue increase contributed to the fiscal surplus from fiscal year 2005 to fiscal

2 See A/RES/70/1. 
Figure 3. Trend in tax revenue in Mongolia

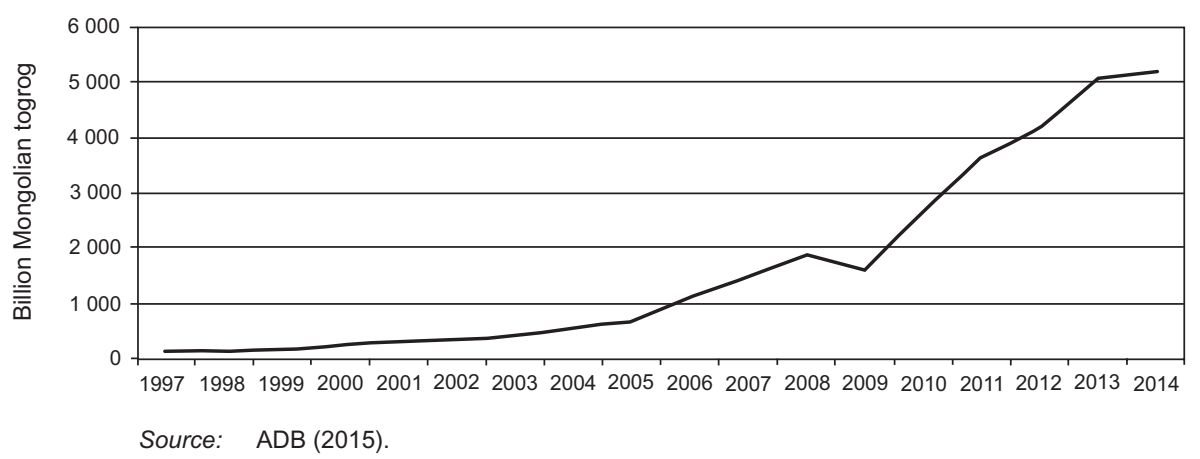

year 2007 (figure 4). Since the economic liberalization in the early 1990s, Mongolia has been undergoing a major transition from being a livestock-based economy to one that is minerals-based. The mining boom, which started in 2003, helped to accelerate economic growth and hence brought the fiscal balance to a surplus in the next few years. However, the fiscal balance returned to a deficit because of market volatility in the commodities market in 2008 and 2009 and the subsequent economic crisis.

Despite these economic vulnerabilities and a poor fiscal performance, tax revenue has in general been growing at a sustainable rate. According the World Bank, "Mongolia's has had a mixed performance in the predictability and control of budget execution. Good progress has been made in tax administration, particularly with regard to the transparency in taxpayer obligations, tax collections..." (World Bank, 2015, p. 11).

Figure 4. Trend in fiscal balance in Mongolia

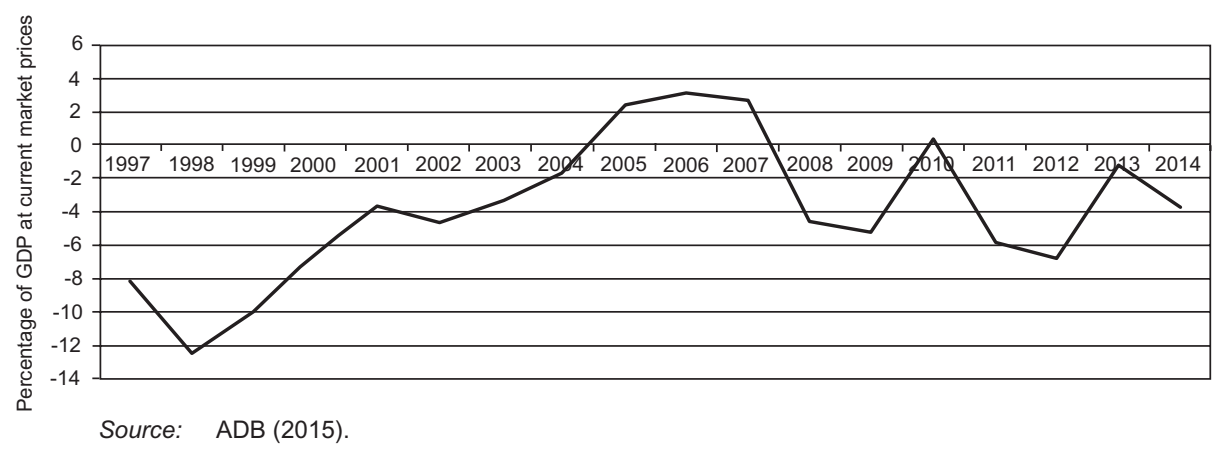


Figure 5. History of Japan International Cooperation Agency technical cooperation

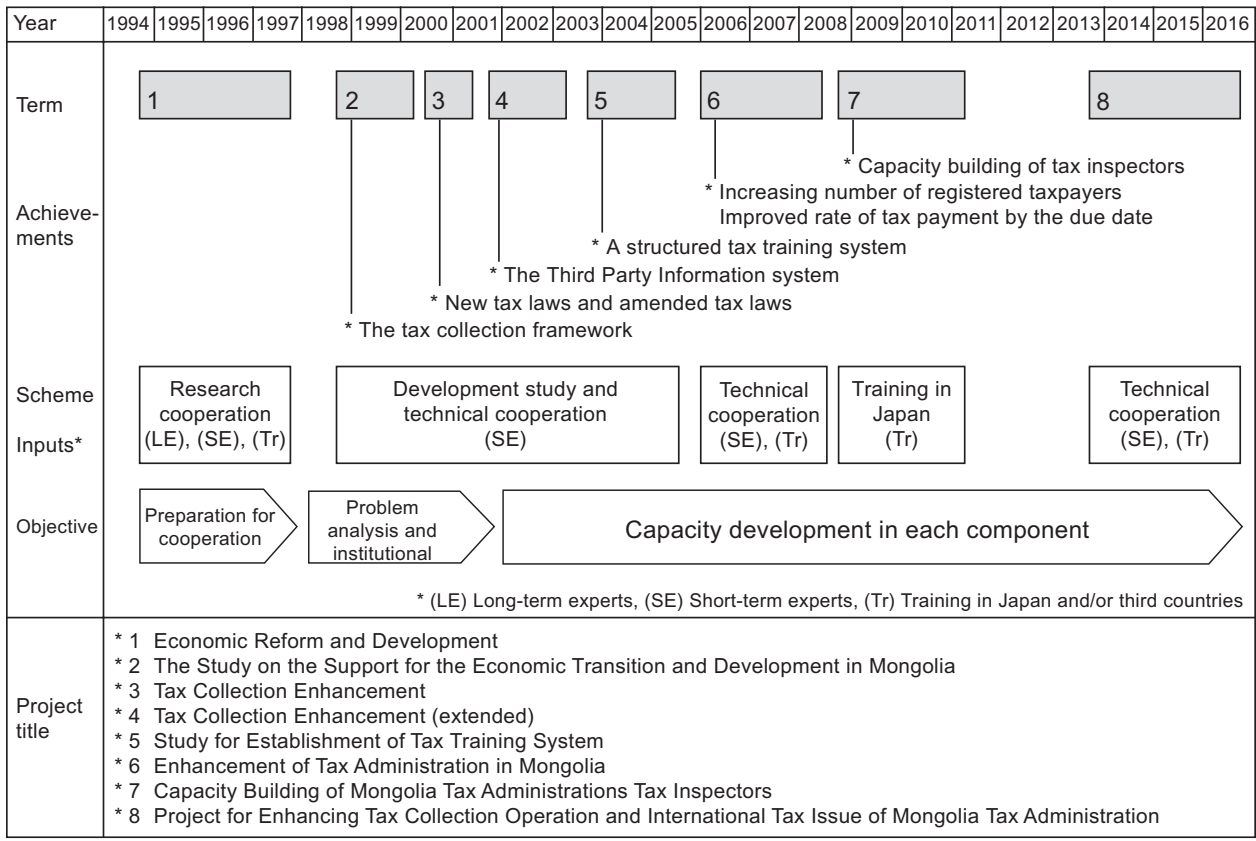

Source: Industrial Development and Public Policy Department, JICA, emailed to author, 9 October 2015.

\section{The first phase: economic reform and development}

JICA initially engaged in technical cooperation from 1994 to 1997 . During that period, it facilitated meetings between key officials of the National Development Board and Japanese researchers on economic reform and development. Research-oriented dialogues between those parties resulted in a proposal on the direction of the marketoriented reform, and the establishment of a joint study group to target capacity development for strengthening public expenditure management and revenue collection.

\section{The second phase: problem analyses on the tax collection framework}

Following the high-level dialogues, the Government of Mongolia and JICA agreed to develop a concrete economic reform programme and human resources development plan to enable more Mongolian technocrats to be in a position to play a leading role in the reform. The joint study began in 1998 between the Ministry of 
Finance and JICA. During the course of the cooperation, they identified areas ripe for tax revenue enhancement and undertook a thorough review and problem analysis of the existing tax framework, including legislation, data collection systems and institutional arrangements (figure 6).

\section{Figure 6. Identified issues and approaches}

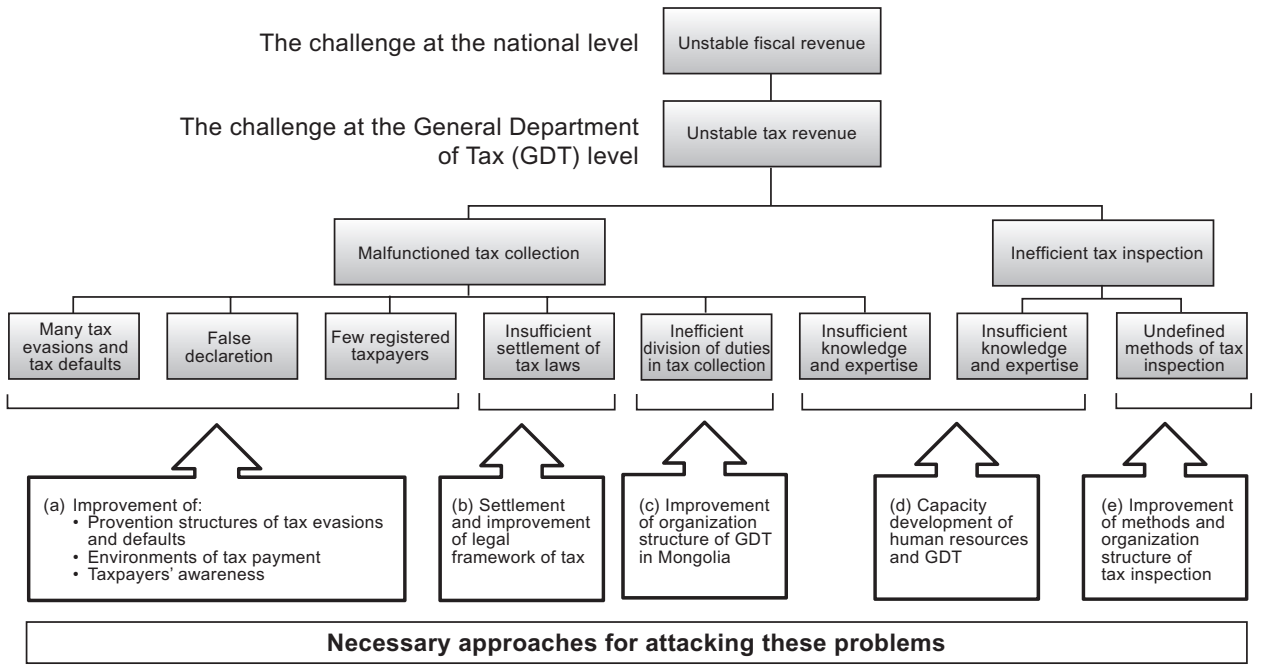

Source: Industrial Development and Public Policy Department, JICA, emailed to author, 9 October 2015.

\section{The third phase: enactment/amendment of the tax laws}

The third phase was implemented in 2000 as a follow-up of the previous phase, between the General Department of Taxation (GDT) and JICA. The second and third phases were important steps during which the study team listed a full range of issues to be tackled by Mongolia while working on more urgent organizational reform and institutional revision. Having reviewed all the tax laws of the country, GDT and JICA recommended the revision of the entire tax law system, which led to the enactment in the Diet session of 2001 on the establishment of a new property tax and special stamp duty, and the revision of laws on personal income tax, corporate income tax, VAT, windfall profit tax, and gasoline and diesel fuel tax, among others.

\section{The fourth phase: information infrastructure for tax inspection}

The improvement of the legal framework of taxation at the earlier stage of cooperation enabled the shift of the focus to the improvement of methodologies and 
organizational structure of tax inspection. During the fourth phase of cooperation, which started in late 2001, the Government of Mongolia and JICA identified insufficient tax inspection practices as taxpayer information tended to remain at each individual inspector and the information useful for efficient tax inspection had not been shared with other organizations. To address this situation, the study team developed a third-party information system, aiming to do the following: ensure informationsharing among tax inspectors; use the information in tax audits; and improve the effectiveness of audits. Information from customs and other government organizations was matched with taxpayer information held by GDT for use in tax auditing. Soon after this was completed, the amount of tax collected increased dramatically, as the system was used to assess supplementary charges and interest penalties.

\section{The fifth phase: staff training and curriculum development}

With the development of the infrastructure required to expand the tax base, the focus area for technical cooperation has gradually shifted to human resources development of tax officials. Some inspectors had been conducting tax examinations and collecting taxes at the inspection sites based on their own interpretations; their practice had been undermining taxpayers' trust in the tax authority. To enable GDT to secure stable tax revenues on a permanent basis, the Government of Mongolia and JICA began to overhaul the training system for tax officials, including the development of curriculum and teaching materials. As a result of a two-year project that was implemented from 2003 to 2005, a new basic policy entitled "National tax inspector education programme and curriculum", was developed, and then approved by the Mongolian tax authority; a short-term programme of action for the period 2006-2008 was formulated; and teaching/learning materials for beginner, intermediate and advanced levels were developed by 2005.

\section{The sixth phase: for quality tax administration}

In August 2005, JICA launched a three-year full-fledged technical cooperation project consisting of three components to enhance the administration of the Mongolian tax authority: human resources development and training; tax collection (including taxation and tax audit); and taxpayer services. Under the project, distance learning programme modules for the tax officers stationed in remote areas were introduced, the work of tax auditors for fairer, more efficient and effective tax collection was reviewed and improved, an enhanced service package at a model service centre for taxpayers was launched and public relations with taxpayers was improved. 


\section{The seventh and eight phases: addressing emerging needs}

Although tax revenue steadily increased and contributed to the fiscal surplus for three successive years, the stability of tax revenue remained intact in 2008. It was commonly recognized that there should be a mechanism to assure the sustainability of quality tax administration. Under these circumstances, the Government of Mongolia and JICA made it possible for Mongolian officials to compare their practices with those of their counterparts in Japan through a three-year technical training programme. The training was a short-term and once-in-a-year programme, but it still helped the participants to learn what needed to be done, namely organizational and institutional capacity development for avoiding tax delinquency and settling delinquent taxes. Additionally, of note, the transition to a minerals-based economy required that the tax authority gain a better understanding of international taxation associated with international mining firms. In response to these emerging needs, JICA launched

Table 3. Approaches adopted in each project phase: summary

\begin{tabular}{|c|c|c|c|c|c|}
\hline \multirow[b]{2}{*}{ Project phase } & \multicolumn{5}{|c|}{ Approaches } \\
\hline & $\begin{array}{l}\text { (a) } \\
\text { Improvement of: } \\
\text { - Prevention structures } \\
\text { - Environment of tax } \\
\text { payment } \\
\text { - Tax payers' awareness }\end{array}$ & \begin{tabular}{l}
\multicolumn{1}{c}{ (b) } \\
Settlement and \\
improvement of \\
legal framework of \\
tax
\end{tabular} & $\begin{array}{l}\quad \text { (c) } \\
\text { Improvement of } \\
\text { organization } \\
\text { structure of GDT in } \\
\text { Mongolia }\end{array}$ & $\begin{array}{l}\quad \text { (d) } \\
\text { Capacity } \\
\text { development of } \\
\text { human resources } \\
\text { and GDT }\end{array}$ & $\begin{array}{l}\quad \text { (e) } \\
\text { Improvement of } \\
\text { methods and } \\
\text { organization } \\
\text { structure of tax } \\
\text { inspection }\end{array}$ \\
\hline $\begin{array}{l}\text { Phase 1: Economic reform } \\
\text { and development }\end{array}$ & & $\mathrm{O}$ & 0 & & \\
\hline $\begin{array}{l}\text { Phase 2: The study on the } \\
\text { support for the economic } \\
\text { transition and } \\
\text { development in Mongolia }\end{array}$ & & 0 & 0 & 0 & \\
\hline $\begin{array}{l}\text { Phase 3: Tax collection } \\
\text { enhancement }\end{array}$ & & (2) & 0 & 0 & \\
\hline $\begin{array}{l}\text { Phase 4: Tax collection } \\
\text { enhancement (extended) }\end{array}$ & & & & O & (2) \\
\hline $\begin{array}{l}\text { Phase 5: Study for } \\
\text { establishment of tax } \\
\text { training system }\end{array}$ & O & & & O & (0) \\
\hline $\begin{array}{l}\text { Phase 6: Enhancement of } \\
\text { tax administration in } \\
\text { Mongolia }\end{array}$ & (2) & & & () & (2) \\
\hline $\begin{array}{l}\text { Phase 7: Capacity-building } \\
\text { of Mongolian tax } \\
\text { administration's tax } \\
\text { inspectors }\end{array}$ & & & & (2) & \\
\hline $\begin{array}{l}\text { Phase 8: Project for } \\
\text { enhancing tax collection } \\
\text { operation and international } \\
\text { tax issues of Mongolian tax } \\
\text { administration }\end{array}$ & 0 & & O & () & \\
\hline
\end{tabular}

Source: Industrial Development and Public Policy Department, JICA, emailed to author, 9 October 2015.

Note: (o-highly relevant; O - relevant. 
a technical cooperation project in 2013 to enhance the tax collection operation of the Mongolian tax administration and help deal with international issues. This project is coming to an end. One of its notable results is the opening of the Tax Debt Call Centre in March 2016.

Table 3 contains a summary of phases and their areas of focus, as explained above.

\section{IMPLICATIONS FROM THE EXPERIENCE IN MONGOLIA}

What are the key takeaways from the experience of JICA in Mongolia for promoting capacity development for DRM?

First, capacity development efforts require a long-term commitment from the global community. When JICA first agreed to provide technical cooperation for economic reform and development in Mongolia in the early 1990s, the concept of capacity development had yet to be fully recognized in the global community, and it had been less common for medium to long-term programmes to address a specific issue of a country. There are many issues to address and many actors to target, but specifically for this report, it was difficult to cover a single project implemented for a short period of time. With regard to capacity of particular individuals or organizations, it takes a longer time for the project counterparts to develop core managerial capacity to use their technical knowledge to deal with problems that may emerge in the future. While technical knowledge can be enhanced even through one workshop, training sessions or even by reports/manuals submitted by external consultants/experts, core capacity can be developed through a long trial-and-error process. Moreover, there is need for a wider perspective of looking at the enabling environment in which efforts of the counterpart organizations lead to positive outcomes and solutions to problems (JICA, 2008).

The time allotted for Mongolia to have enhanced capacity for tax administration could have been shortened if JICA had reviewed the issues more thoroughly at the initial stages. However, it should be noted that capacity development for DRM may take time. No matter how many development partners may be working on this specific agenda, there needs to be a mechanism to assure their long-term commitment. Traditional donors from the North are better equipped to deal with this issue as their country offices and country teams have a long accumulated knowledge base on the agenda.

Second, capacity development for DRM may call for the commitment of the global community in a more concerted manner. In the early 2000s, JICA conducted a thorough review of technical cooperation projects it had implemented around the 
world and came to a conclusion that the concept of capacity development requires a change in its mindset of being inclined towards result management at the individual project level to being programme-based, combining different types of operations and projects to meet the national development goals and strategy (JICA, 2006). In retrospect, its experience with the Mongolian tax administration seems to have been in line with the conclusion. Of course, when the project was developed, there were no expectations that it would entail such a long-term engagement. If JICA had taken a comprehensive approach from the beginning based on the problem analysis set out during the second phase and if it had believed that addressing the capacity needs at all levels would be difficult for a single effort by JICA, there should have been collaboration with the efforts of other development partners. The comprehensiveness of the programme should also be reviewed periodically to see if it addresses the issues and approaches of all the stakeholders. During the seventh phase, the Mongolian tax authority and the JICA Mongolia Office contacted the Ministry of Education, Culture and Science as well as local media about the development and dissemination of a curriculum for tax education and awareness campaigns. These efforts contributed to the integration of the school curriculum and rallied public support for paying taxes. The objective of the multi-stakeholder framework of capacity development was to approach the "society" for a sustainable tax system in Mongolia. However, such a necessity was not identified at the initial problem analysis and seemed to have emerged at the later stages.

Third, capacity development enhancement must go hand-in-hand with strong country ownership. This reconfirms the key argument on aid effectiveness over the last decade and statements made by the Global Partnership for Effective Development Cooperation (GPEDC), which argued that the host country ownership could bring the country-specific contexts into the institution to be built and would lead to greater sustainability in capacity development. As for tax administration in Mongolia, high-level dialogues on problem analysis and institutional design at the initial stage of the project in the late 1990s helped to build a foundation for all the stakeholders. This prompted lawmakers to develop a strong interest in the progress of the programme. During the course of project implementation, JICA experts also respected the local efforts and tried to gradually reduce the Japanese presence so that their counterparts could play a leading role. These arrangements brought about a strong sense of ownership on the Mongolian side. Maki Hamaoka of the Foundation for Advanced Studies on International Development referred this during interviews with a few key officials of the tax authority:

[l]n addition to the proposal from the Japanese side we expressed our preference and opinions about things that were untenable in Mongolia. As a result, the program was implemented incorporating opinions from 
both sides though we had heated discussions at times. We could move in the direction we intended. (Hamaoka, 2015, p.19)

Hamaoka also interviewed the JICA experts involved in the project. In the earlier years of cooperation, heated discussions occurred frequently, but the Japanese tried to consider the feelings of their counterparts to maintain mutual trust. These earlier efforts bore fruit later:

[W]e could make substantive technical transfer since around Phase 2 and the state became stable around Phase $3 ; \ldots$ in Phase 5 , the counterpart could handle creation of teaching material for training and collection of cases for inspection alone without Japanese experts' presence in Mongolia. (Hamaoka, 2015, p. 20)

Similar to cases at the institution and organization level, capacity development at the individual level may take time. However, having completed the interviews with the key stakeholders, Hamaoka concluded that respect for the ownership from the earlier stages of the programme has guaranteed sustainability of the subsequent projects. During the absence of the JICA experts, the staff of the JICA country office maintained the dialogues. Sometimes they served as intermediaries for the Japanese expert group, and sometimes as primary counterparts on policy consultations with their Mongolian counterparts.

Last but not least, it should be noted that the focus of a quick-impact project should be on showing quick results, and then shift to the next measures to ensure long-term institutional sustainability. As mentioned above, after the problem analysis at the initial stage of the tax collection framework, the Government of Mongolia and JICA focused first on enacting new tax laws and amending the existing ones. The establishment of the legal framework drew the attention of the senior government officials. In that regard, Hamaoka wrote the following:

[S]teady improvement through cooperation in the area with a high degree of urgency enabled people on the counterpart to see the improvement effect, which further strengthened the ownership of the counterpart. We can also assume that such achievement will generate incentives and confidence in the field. (Hamaoka, 2015, p.19)

Quick-impact projects require a certain degree of selectiveness and resource concentration. As the track record of the Mongolia-Japan cooperation shows, thorough problem analysis at the initial stage was followed by the enactment/ amendment of the tax laws in the third phase, information infrastructure for tax inspection in the fourth phase, and staff training and curriculum development in the fifth phase. Following the full-fledged technical cooperation project in the sixth phase, 
the focus shifted to individual capacity development of selected tax inspectors in the seventh phase, and then to the control of tax delinquency and institutionalization of international taxation in the eighth phase. The change in focus of the cooperation made it possible to concentrate on human resources of the two countries and then to be results-oriented.

\section{CONCLUSION - TRANSITIONAL ROLE OF INTERNATIONAL COOPERATION}

In the coming decades, emerging economies, the private sector, nongovernment organizations (NGOs), local governments, and academia and epistemic communities will play a more important role in efforts to achieve sustainable development. Development of information and communications technology (ICT) will scale up the efficiency of operations and policy implementation and deepen interactions among those actors at an unprecedented rate. Under such circumstances, the expected roles of ODA and international cooperation in the future could be defined as the follows:

(a) It should support the provision of domestic public goods and services, especially among lower-income countries, in such sectors as education, health and basic infrastructure.

(b) It should act as a catalyst in developing countries to encourage private resource mobilization by correcting market failure and ensure a conducive investment climate for FDIs, technological innovation, venture capital and social business by providing aid for investment in economic infrastructure, partial risk guarantees and facilitating knowledge-sharing.

(c) It should supply international public goods to address global and regional issues by providing a platform for knowledge creation and sharing.

The ECDPM report also refers to the role of international public finance, arguing that it should be used in a more focused and catalytic manner, referring to tax capacity and vulnerable groups in the transformation as potential focus areas for development finance institutions. This is in line with the above argument on the role of ODA in general.

As highlighted in the case of Mongolia, international cooperation can also play a key role in lower-income countries and lower-middle-income countries to increase public revenues to move upward to the higher brackets of development stages. In Mongolia, under the strong country ownership, JICA implemented technical cooperation projects in a programmatic way. In this case, international public finance 
was provided through technical cooperation. It facilitated capacity development aimed at enhancing the tax administration of the country.

Now that Mongolia has progressed to become a member of the upper-middleincome group of the World Bank country classification, the time may be ripe for the country and the rest of the world to consider the next step in its development path. While JICA is still supporting the Mongolian tax authority in addressing emerging issues, such as international taxation, it should also bear in mind that the measures applied could be widely shared with other lower-income countries and lower-middleincome countries that have dealt with similar bottlenecks in efforts aimed at DRM. This opportunity for mutual learning could also be facilitated by international public finance.

In response to strong demands from Member States, the United Nations specialized agencies and the multilateral development banks have been organizing knowledge-sharing workshops or establishing semi-permanent platforms for the early achievers to share their experience regionally or globally. Facilitation of South-South cooperation and triangular cooperation help countries overcome financing gaps with regard to development cooperation, limited experience in matching needs and resources, and complexity in institutional development without affecting the country ownership.

This is an aspect also highlighted in the Sustainable Development Goals as Goal 7.9, "Enhance international support for implementing effective and targeted capacity-building in developing countries to support national plans to implement all the Sustainable Development Goals, including through North-South, South-South and triangular cooperation." ${ }^{3}$ In the context of promoting DRM, first, international cooperation should concentrate on capacity development for a particular country. The earlier efforts of the traditional donors from the North could facilitate the participation of emerging donors in a concerted manner. However, this could also mean that it should scale up the capacity development efforts by facilitating triangular cooperation to engage a number of countries for the promotion of DRM.

See A/RES/70/1. 


\section{REFERENCES}

African Development Bank (AfDB), and others (2015). From billions to trillions: transforming development finance post-2015 financing for development: multilateral development finance. Paper prepared for the Development Committee meeting. 18 April. Available from http://siteresources.worldbank.org/DEVCOMMINT/Documentation/23659446/DC20150002(E)FinancingforDevelopment.pdf. Accessed 15 October 2016.

Asian Development Bank (ADB) (2015). Key Indicators for Asia and the Pacific 2015. Manduluyong City, Philippines.

Hamaoka, Maki (2015). Japan's 10-year technical cooperation in Mongolia for tax administration. Available from http://gwweb.jica.go.jp/km/FSubject1001.nsf/b9ebd9a793e2456249256 fce001df569/7a423687582f26fc49257e37002428df/\$FILE/\%5BEnglish\%5DTax\%20 Administration\%20in\%20Mongolia.pdf. Accessed 15 October 2016.

Overseas Development Institute (ODI), and others (2015a). European Report on Development 2015: Combining Finance and Policies to Implement a Transformative Post-2015 Development Agenda. Brussels: European Union.

(2015b). European Report on Development 2015: main messages. Presentation at the Japan/JICA Joint Seminar on Presentation of the ERD. Tokyo, 11 March.

Schmidt-Traub, Guido (2015). Investment needs to achieve the sustainable development goals: understanding the billions and trillions. SDSN Working Paper Version 2, 12 November.

United Nations (2014). The road to dignity by 2030: ending poverty, transforming all lives and protecting the planet. Synthesis report of the Secretary-General on the post-2015 agenda. New York, 4 December. Available from www.un.org/disabilities/documents/reports/ SG_Synthesis_Report_Road_to_Dignity_by_2030.pdf.

World Bank (2015). Mongolia economic update. November 2015. Available from http://pubdocs. worldbank.org/pubdocs/publicdoc/2015/11/920971447119845335/meu-nov2015-en.pdf. 